\title{
CORRIGENDUM
}

\section{Chromosomal, epigenetic and microRNA-mediated inactivation of LRP1B, a modulator of the extracellular environment of thyroid cancer cells}

H Prazeres, J Torres, F Rodrigues, M Pinto, MC Pastoriza, D Gomes, J Cameselle-Teijeiro, A Vidal, TC Martins, M Sobrinho-Simões and P Soares

Oncogene (2017) 36, 146; doi:10.1038/onc.2016.143; published online 8 August 2016

Correction to: Oncogene (2010) 30, 1302-1317; doi:10.1038/ onc.2010.512; published online 8 November 2010

Following the publication of this article, the authors realised that the following information had been missed from the acknowledgements section:
This work was also supported by FEDER funds through Programa Operacional Factores de Competitividade-COMPETE (FCOMP-010124-FEDER 011267).

The authors apologise for any inconvenience caused by this error. 